\title{
228 織毛・鞭毛における微小管の滑りを規範としたマイクロマニピュレータ開発の基整研究 Basic Study for the Development of Novel Micromanipulator Modeled on Sliding Mechanism of Microtubules in Eukaryotic Flagella and Cilia
}

\author{
藤原 和正（信州大） \\ 正 小林 俊一 (信州大) \\ 東鄉 正樹（信州大院） \\ 正 森川 裕久（信州大） \\ Kazumasa FUJIHARA, Masaki TOGO, Shunichi KOBAYASHI, Hirohisa MORIKAWA \\ Shinshu University, 3-15-1, Tokida, Ueda, Nagano
}

\section{1. はじめに}

真核生物の鞭毛や繊毛は,それらの内部にある微小管を能動的に 滑らせて連続的な届曲運動を実現している. 著者らはこれまでこの

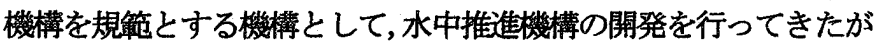
(1), 本研究ではマイクロマニピュレータとしての開発を目的とし ている. 本報では, 微小管の滑りを圧電素子と摩擦異方性を持つ毛 䯽を用いて再現した届曲機構を考案, その開発のための基礎実験結 果について述べる.

\section{2. 作原理と实畭特監}

2. 1 鞭毛·䋐毛の屈曲モデル

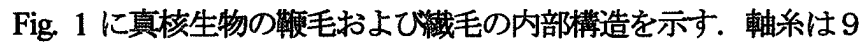
本の周辺小管と 2 本の中心小管からなり, $9+2$ 構造と呼ばれてい る.この周辺小管にはダイニンといらたんぱく質の突起構造があり， ダイニンは ATP 加水分解の化学的なエネルギーにより, 隣の微小 管を一定方向に動かす滑り力を発生している'(2). Fig. 2 に屈曲のメ カニズムを示す.ある 1 本の微小管のダイニンが全長にわたって一 斉に滑り力を発生させるのではなく，微小管が滑っている領域 (Sliding Region)，滑りに抵抗する領域 (Fixing Region)，力を発せ ず自由に曲げられる領域（Bending Region）の存在によって届曲が 発生する.

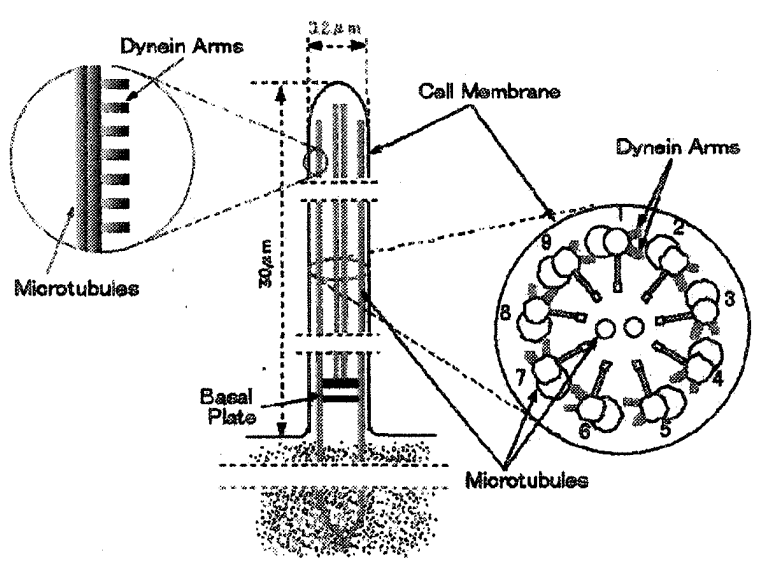

Fig. 1 Typical structure of eukaryotic flagella and cilia

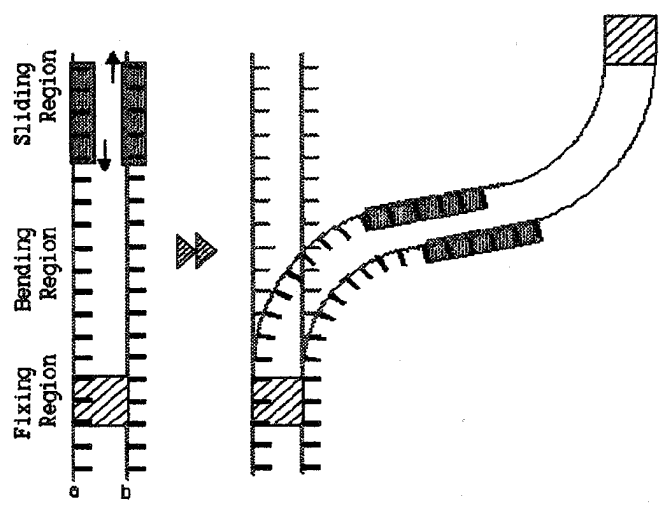

Fig. 2 Bending mechanism of flagella and cilia

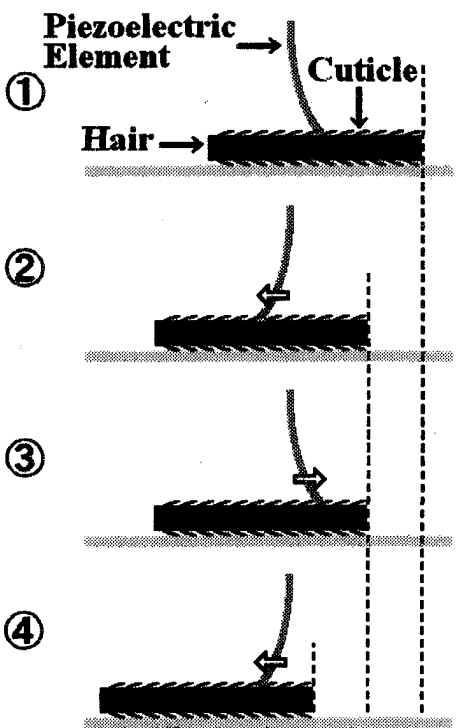

Fig. 3 Principle of hair movement driven by piezoelectric element

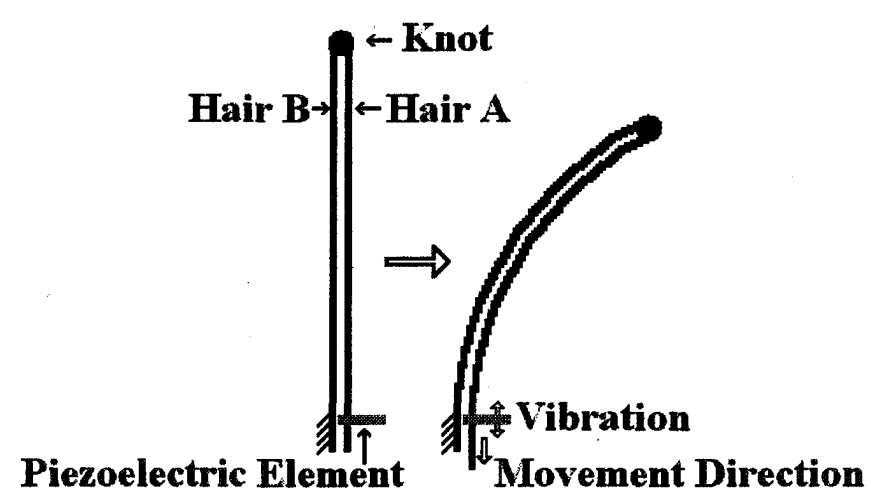

Fig. 4 Bending mechanism of two hairs

\section{2 屈曲機棈の動作原理}

ダイニンの動きを規範としたアクチュエータとしてバイモルフ 型圧電素子を用いる.また，微小管は一定方向にのみ滑ることから， キューティクルによって摩擦の異方性を持つ毛髮を用いて,この動 作を再現する.

微小管の滑り運動に相当する毛髪の移動原理を Fig. 3 に示す. 同

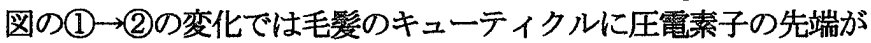
引つかかるため, 圧電素子が左へ屈曲すると共に毛影も左に移動す る. (2)ー(3)の変化では圧電素子が毛髪のキューティクル上をすべる ため圧電素子は右側入屈曲を起こすが, 毛髪は移動しない. (3)↔(4) では(1)ー(2)の変化と同様にさらに左へ移動する.この動作を繰り返 すことによって垄髪は一定方向に移動することになり,実際のダイ ニンと微小管の滑り運動に似た運動をすることができる.

Fig. 4 に屈曲のメカニズムを示す.二本の毛髪 A, B の先端を結び, 毛髮の間隔を一定に保った状態で毛髪Aを図のように移動させる と, 先端までの長さの差によって屈曲を形成することができる. 


\section{3 实験装置と測定方法}

実験装置をFig. 5 に示す. 中心部分の圧電素子はファンクション ジェネレータにより矩形波の霓圧を印加し屈曲させる（電圧は $\left.20 \mathrm{~V}_{\text {P.p }}\right)$. なお, 圧電素子の枚数 $N$ やその間隔 $d$ を変化できるよう に圧電素子の支持部には複数の圧電素子支持用のスリットを設け た. 圧電素子は有效長さ $l=13.0 \mathrm{~mm}$, 幅 $w=3.03 \mathrm{~mm}$, 厚さ $t=0.26$, ヤング率 $Y_{11}^{E}=6.2 \times 10^{10} \mathrm{~N} / \mathrm{m}^{2}$, 密度 $\rho=7.5 \times 10^{3} \mathrm{~kg} / \mathrm{m}^{3}$ であり, 理論 共振周波数 $f_{m}$ は次式( ${ }^{(3)}$ により $616 \mathrm{~Hz}$ である.

$$
f_{m}=\frac{1.875^{2}}{4 \sqrt{3} \pi} \cdot \frac{t}{l^{2}} \sqrt{\frac{Y_{11}^{E}}{\rho}}
$$

上部のネジにより圧電素子と毛髮の間隔を調整できるようになっ ている.また，毛鬅の下部にはPTFE シートを敷き，底面との摩擦 を低くした. 毛髮の移動速度は, ビデオカメラによって毛箎の移動 を撮影し，その画像の1コマあたりの移動量を測定し求めた.

\section{3. 結舆および接案}

\section{1 移動速度}

圧電素子を 1 枚 $(N=1)$ とした際の圧電素子に印加する電圧の周波 数と毛髮（直径 $0.07 \mathrm{~mm}$ ，長さ $20 \mathrm{~mm}$ ）の移動速度の関係を Fig. 6 に示す.この結果より，周波数が上がるにしたがって移動速度も大 きくなり, $600 \mathrm{~Hz}$ でピークとなる. これは圧電素子の理論共振周波 数が $616 \mathrm{~Hz}$ であるためであり，それ以上の周波数では変位が小さ くなるため, 移動速度が小さくなったと考えられる。

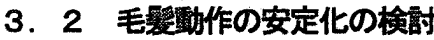

安定した動作をするために圧電素子を 2 枚 $(N=2)$ に増やし, 間隔 $d$ を変化させた. なお，2枚の圧電素子の振動の位相差は Odeg とし た. その際の移動速度を Fig. 7 に示寸. 圧電素子に印加する電圧の 周波数は3．1の結果より $600 \mathrm{~Hz}$ とした，これより，圧電素子の 間隔 $d$ が $6 \mathrm{~mm}$ の時が最もバラつきが少なく，移動時間も長かった ことから最も安定しているといえる. また，2枚の圧電素子の振動 の位相差を 180deg として検討したが，毛髮の移動は見られなかっ た.

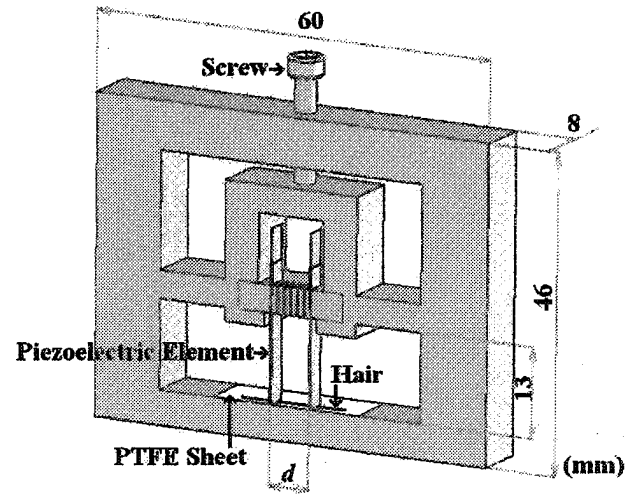

Fig. 5 Experimental device

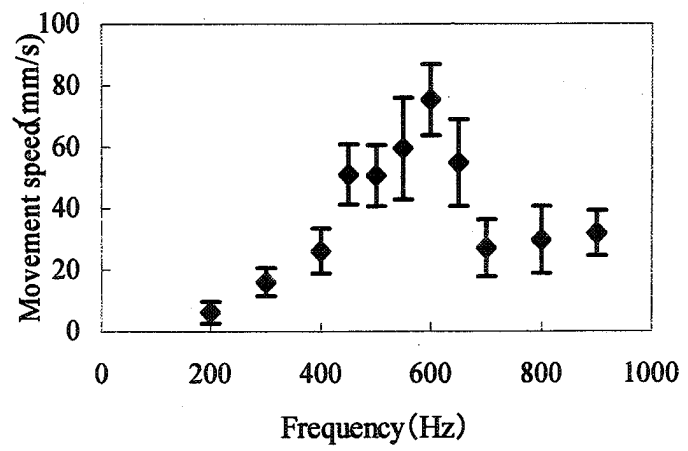

Fig. 6 Relationship between movement speed of a hair and applied voltage frequency to a piezoelectric element $(N=1)$

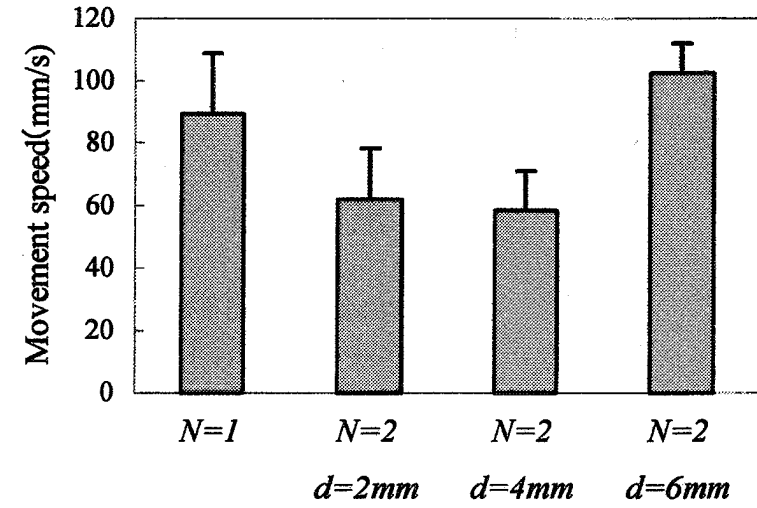

Fig. 7 Movement speed of a hair $(600 \mathrm{~Hz})$

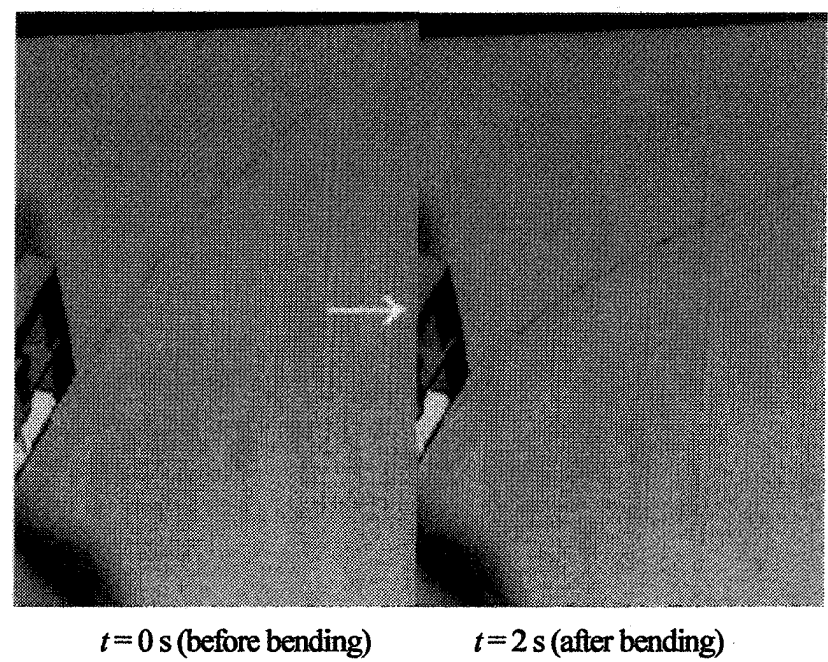

Fig. 8 Bending movement of a hair $(600 \mathrm{~Hz}, N=1)$

\section{3 風曲動作}

二本の毛髮（直径 $0.07 \mathrm{~mm}$ ，根元から先端までの長さ $110 \mathrm{~mm}$ ）を 使用した届曲の様子を Fig. 8 に示す. なお, 圧電素子に印加する電 圧の周波数を $600 \mathrm{~Hz}$ ，圧電素子の枚数 $N$ を 1 とした. 同図より，2 秒で右方向への屈曲を見ることが出来た. 先端の移動距離は $29 \mathrm{~mm}$ であった。

\section{4. おわりに}

真核生物の鞭毛や瀻毛の内部にある微小管の滑りによる屈曲運 動機構を規範とするマイクロマニピュレータとして, 圧電素子と摩 擦異方性を持つ毛䐅を用いた屈曲機構を考案，すべり速度に相当す る毛琹の移動速度を検討した.これより，圧電素子の共振周波数付 近において毛栵の移動速度が最大になり，圧電素子を 2 枚使用する ことで安定した移動が得られた. また，2本の毛筍による屈曲につ いて検討した. 今後の課題として，2本の毛髮の間隔を一定にした 屈曲の定量的な評価を行うこと,左右一の連続的な屈曲運動を実現 することが挙げられる. 最後に, 実験装置の作製にあたり指導して いただいた，本学技術職員 市川富士人氏にお礼申し上げる.

\section{都文献}

(1) Kobayashi, S., et al., JSME International Journal, Series C, Vol. 44, No. 4, (2001), pp. 946-951.

（2）日本機械学会編，細胞のバイオメカニクス，オーム社，(1990), pp.164-165.

(3) 株式会社富士セラミックス, 圧電セラミックテクニカルハンド ブック, http://www.fujicera.co.jp/contact/j/index.html, p.45. 